\title{
GOVERNANCE, SOVEREIGNTY AND GLOBALISATION
}

\author{
Sir Kenneth Keith*
}

The 5th Biennial Conference of the NZ Council of Trade Unions had as its main theme "The Next Decade - Te Takau Heke Iho". In his address to that conference Sir Kenneth Keith spoke about the end of democracy and of the nation state. Sir Kenneth discussed the role of international law in globalisation, and the transformation of the organisation of public powers. Key areas of international activity were examined and options for regulation were proposed, including public and private regulation. Sir Kenneth noted the need for greater dissemination of information on international rules and treaties, including public involvement during treaty negotiation. Finally, Sir Kenneth discussed implementation concluding that a mixture of national and international methods of implementation may be most appropriate. The speech is reproduced here.

\section{THE END OF DEMOCRACY?}

Four years ago the French Ambassador to the European Union published a book entitled The End of Democracy, La fin de la démocratie. ${ }^{1}$ The chapter headings give a sense of his argument. They include "The End of the Nation", "The End of Politics", "An Empire without an Emperor", "Religions without God", "Imperial Violence" and the "Imperial Age".

\section{OR OF THE NATION STATE?}

When two years later the book was translated into English The End of Democracy had become The End of the Nation State. ${ }^{2}$ The alternative titles and the chapter headings show that the Ambassador is addressing the very issues which you have asked me to speak about today. I might suggest that instead of listening to me that you read Jean-Marie Guéhenno's "brilliant essay", a "book of remarkable intellectual range" - to quote the commendations of Elie Wiesel and the Economist. Alternatively you might read the latest

* Judge of the Court of Appeal of New Zealand.

1 (Flammarion, 1993).

2 (University of Minnesota Press, Minneapolis, 1995). 
Human Development Report ${ }^{3}$ prepared by the United Nations Development Programme which, like many others who have written about the same theme in recent years, provides some of the facts and figures supporting the Ambassador's elegant argument. This is what the Ambassador says about the Nation:4

Too remote to manage the problems of our daily life, the nation nevertheless remains too constrained to confront the global problems that affect us. Whether it is a question of the traditional functions of sovereignty, like defence or justice, or of economic competencies, the nation appears increasingly like a straightjacket, poorly adapted to the growing integration of the world.

The UNDP puts it this way, beginning with a question: ${ }^{5}$

Are states becoming irrelevant? At one level they are being resisted by ethnic and other groups pressing for greater autonomy and self determination. At another they are being bypassed by multinational corporations that care little about local jurisdictions. They seem to have become too big for the small things and too small for the big.

And a little later 6

Today's global integration is wiping away national borders and weakening national policies. A system of global policies is needed to make markets work for people, not people for markets.

The Ambassador had earlier made the point that the state was poorly equipped to collect taxes, because of the mobility of investment and talent, and hardly more effective in managing spending. He continues by calling attention to the huge problems with defence policy and then, to move into an area with which I am somewhat more familiar, he turns to the legal system. ${ }^{7}$

No legal system can claim to be immune from international influences, as the increasing importance of the law elaborated in Brussels in a regulation of the different countries of the European Union clearly shows.

This constraint is not only the consequence of an institutional construction resulting from a political will. It reflects the evolution of economies and the need to conform to international norms, which define themselves on a supranational level: a country that isolates itself within

3 UNDP, (Oxford University Press, New York, 1990).

4 Above $\mathrm{n} 2$.

5 Above n3, 91

6 Above n3.

7 Above n2, 15. 
particular juridical norms, believing that it will protect its industry from incursions from abroad, deals its industries a fatal blow, for it seals its cutting edge industries within a market too restrict to allowed for the amortisation of research expenditures and the development necessary to maintain competitivity.

He completes that first chapter, "The End of the Nation", with this question: ${ }^{8}$

If solidarity can no longer be locked into geography, if there is no longer a city, if there is no longer a nation, can there still be politics?

The Ambassador sees the end of the nation state as the end of the period which began not in 1945 or in 1917, two of the dates commonly accorded, but in 1789 with the French Revolution. The era, beginning 200 years ago was, he says, the era of institutionalisation, as compared with the imperial age which he sees as returning. Some, especially international lawyers, would go back another 150 years to the Peace of Westphalia of 1648, almost 350 years ago, which is often seen as the beginning of the modern international system of so called sovereign states. We tend to think of that system as a given which has always existed. But it is a human construct and depending on your view of time a relatively recent one at that. There is nothing inevitable about it. The modern state has existed, for instance, for less than half of the time that universities have.

\section{SOME FACTS}

The UNDP report under the heading "The Shrinking World" gives some of the facts and figures supporting that heading and other expressions such as "the global village" and "the world without borders". It mentions, for instance, the massive declines in the costs of transport and communication in recent decades. The cost of maritime transport, it says, has dropped over the last 70 years to about a third of what it was and the cost of airlines per mile flown has dropped about the same in just 30 years. The cost of international telephone calls has dropped much much more to about $1 / 50$ th, as I read the figures, since $1940 .^{9}$

There has been an amazing increase, matching those figures, in the use of those technologies. The number of people flying in and out of New Zealand over the last 40 years has increased from about 50,000 per year to 4,000,000. In 1950 New Zealanders, in the course of whole year, made 5,793 outward telephone calls, or just under 16 a day. We know that since the Post Office carefully recorded each and every one. When the information was last publicly available the daily figure had reached nearly 100,000 and that figures takes no account of faxes and email. The UNDP says that the use of the

8 Above $\mathrm{n} 2,17$.

9 Above n3, 83. 
internet is doubling every year. Telecommunications are increasing at $20 \%$ per year. The huge information flows across the globe have transformed the way in which business is done in transformed political systems. Consider, for instance, their impact in the momentous events of 1989 .

Kenichi Ohmae, one of whose books is also entitled The End of the Nation State, ${ }^{10}$ emphasises information technology among his four Is. The others are investment, industry and individuals, especially as consumers. All are now much more mobile than was once the case. But some things, the UNDP reminds us, are not that different. Very helpfully its Human Development Report recalls that for 17 industrial countries for which there are data, their exports as a share of GDP were $12.9 \%$ in 1913, not much below the 1993 level of $14.5 \%$. Capital transfers as a share of industrial country GDP are still smaller than in the 1890s, and earlier eras of globalisation saw far greater movement of people around the world. Today immigration is more restricted. That reminder of history and the particular date of the export figures helps highlight the continuing significance of one of the preambular paragraphs to the constitution of the International Labour Organisation, adopted at Versailles in 1919:

The failure of any nation to adopt humane conditions of labour is an obstacle in the way of other nations which desire to improve the conditions in their own countries.

The representatives at Versailles did not simply set up mechanisms and recognise commercial reality in that preambular paragraph. As well they stated principles including the guiding principle that labour is not to be regarded merely as a commodity or article of commerce, the right of association of employed persons as well as of employers, adequate pay, the eight hour day and 48 hour week, abolition of child labour, equal remuneration for work of equal value for men and women and inspection to ensure enforcement.

\section{REQUIRING INTERNATIONAL STANDARDS AND PROCEDURES}

The Director-General of the International Labour Organisation in his most interesting report, The ILO, Standard Setting and Globalization submitted to this year's International Labour Conference has recalled the understandings that surrounded the standard setting process at the outset of the organisation. He said this: ${ }^{11}$

Although they had to bend to reality and give up the revolutionary idea of giving the International Labour Conference a legislative power which was directly binding on States (in particular to ensure that legislative progress did not become hostage to a reactionary minority),

10 (Harper Collins, London, 1995).

11 Standard Setting and Globalisation: Report of the Director-General 85th session, 1997, 50. 
it remained clear in their minds that a government, by voting in favour of the adoption of a 
Convention, undertook the moral commitment to bring about its ratification. ${ }^{12}$ Only this can explain the presence - which today seems so incongruous - of special provisions aimed at certain countries expressly mentioned in a number of the first Conventions. ${ }^{13}$ It is in this context, that one can also understand better the conviction, so widely shared before the Second World War, that international labour legislation should contribute effectively towards equalizing conditions for competition and (and a contrario the criticisms of the Office made by the British employers at the beginning of the 1930s and that it had not succeeded in adequately promoting ratifications more than ten years after the creation of the Organization). ${ }^{14}$ It might admittedly be conceded that a government could in all good faith and in full knowledge of its responsibilities vote for a text knowing well that it would be impossible to ratify it for the time being, provided that it felt that this instrument might further the cause of international labour legislation and that it envisaged ratifying it in the longer term.

Over 75 years ago there was then an understanding that states were increasingly committing themselves to international standards governing matters previously seen as domestic. So far as labour standards were concerned the process had begun shortly before in 1906 with the International Conventions for the Prohibition of the Use of White (Yellow) Phosphorus in the Match Industry and for the Prohibition on Night Work for Women but, as I will mention in a moment, it goes back further in respect of other human rights issues. Already questions were arising about the value of the word sovereignty, at least if it was understood in any absolute sense, see Brierly, "The Basis of Obligation in International Law". ${ }^{15}$ It obviously could not have its full meaning even in a world of independent states with one exercising its independence in relation to the others : they could not be both equal and sovereign. But now the standards set by the international community were increasingly entering into matters previously seen as domestic. They were in particular beginning to regulate the relationships between employers and employees.

Let me take a contemporary New Zealand instance in respect of another aspect of economic activity. It is also a more orthodox international matter. New Zealand's exports constitute about one-third of its gross domestic product. Imports are at an equivalent level. The law governing that extensive economic activity can only in a very

12 This is the meaning a contrario of a speech given by Albert Thomas to the Third Session of the International Labour Conference, 1921, Record of Proceedings, Vol. 1, 219.

13 See, for example, Conventions Nos. 1, 4, 5 and 6.

14 ILO; Record of Proceedings, 15th Session of the International Labour Conference, Geneva, 1931, Vol II, 3-5.

15 (1928) in Lauterpacht and Waldock (eds) The Basis of Obligation in International Law and Other Papers (1958) 1, 19-33, 40-46, 59, 62. 
limited sense be the law of New Zealand. In fact so far as goods are concerned the bulk of the activity is governed by the Convention on the International Sale of Goods to which New Zealand became party two years ago. In addition to that Convention, developed by the United Nations Commission on International Trade Law, confirmed by the Diplomatic Conference of government representatives and enacted into national law by national parliaments, there is a huge volume of private ordering of international commercial activity. Some of this arises from standard form contracts, such as those issued in respect of insurance and shipping. Some is developed by the International Chamber of Commerce, again through standard terms and conditions. In other cases a particular industry may develop its own rules and indeed courts, as with the international diamond market where a body of law is developed and administered in the 20 bourses which run that industry, a body of law which has, according to a recent scholarly account, only once been the subject of national court consideration, Bernstein "Opting out of the legal system : extra-legal and contractual relations in the diamond industry". ${ }^{16}$ Or matters might be left to developing commercial practice.

\section{$V \quad$ WHICH MIGHT BE SET PRIVATELY AS WELL AS BY GOVERNMENTS}

As well, international activity through private means is frequently facilitated by standardisation and not by government action at all. That is to be seen, for instance, in the area of broadcasting and, to reintroduce governments, munitions.

Many other examples can be chosen not only from industry but also, for example, from international sport, connected closely these days to international communications. The examples illustrate that what we see when we look at the powers of once sovereign states is a three way movement of their power: to subordinate state instrumentalities, for we should recall that the UNDP referred to states as being too large for some purposes, to international arenas, not simply in Europe but within the world community as well, and increasingly into private hands.

As Kofi Annan, the new Secretary-General of the United Nations has said, some of that private activity is a manifestation not of the civil society but the uncivil one. $\mathrm{He}$ instances drugs, as does Ambassador Guéhenno. ${ }^{17}$

The economy of drugs is a good illustration of this bypassing of states by transnational games that are far more powerful than are the states themselves. Everywhere that the state is weakened or the climatic conditions are favourable, drugs take root, profoundly transforming society. So it comes as no surprise that Latin America, but also Afghanistan and Lebanon, are

16 (1992) 21 JLE 115.

17 Above $\mathrm{n} 2,3$ 
important centres of production and processing. These days, the revenues generated by drugs are greater than the total public aid for development reported by the Committee for Development Aid - an estimated $\$ 100$ billion. The effect of a suppression of the drug trade would therefore doubtless have more impact than would be that from a halt in the politics of public aid for development. Coca and the opium poppy are the only agricultural crops in the Third World that are flourishing. In some states there is no difference in the scale of revenues from drugs and that of the budget. With drug money, one could almost buy certain Third World countries; the public-interest sphere is now within the reach of private fortunes. It is, if one dare say it, an extreme form of privatization.

The UNDP, as well, calls attention to crimes whether relating to drugs, abuse of women, embezzlement or corruption that transcend frontiers and have become similar everywhere. An excellent recent book by leading British economist, Susan Strange, called somewhat more modestly The Retreat of the State: The Diffusion of Power in the World Economy, ${ }^{18}$ gives particular attention to organised crime as one of the author's five factual studies supporting her theoretical argument about the declining authority of states. The others are telecommunications, insurance, the big six accountants, cartels and private protectionism and international organisations: the econocrats.

Her conclusion relating to the Mafia refers to what she sees as two intrinsically conflicting decisions - on the possession and sale of stupefying or hallucinatory drugs, and on financial transactions through the banking system involving clean and dirty money: ${ }^{19}$

[Her study] suggests that the models of international society conventionally accepted in the realist, the neo-realist and in the neo-liberal literature of international relations may have been rendered obsolete by changes in the world market that have indirectly eroded the authority of states.

Ever since the Westphalian treaty in Europe, it has been held that the determination of what was and what is not 'the wrong side of the law' lay in the last resort with the governments of territorial states. It was up to them to decide what actions or associations of residents within their borders were within the law and what were beyond it - illegal, criminal. In recent years, however, the majority of such governments have taken two intrinsically conflicting decisions on the possession and sale of stupefying or hallucinatory drugs, and on financial transactions through the banking system involving clean and dirty money. The first has been declared the wrong side of the law. The second has been tacitly admitted as being on the right side, inasmuch as only the most feeble attempts have been used to make the banks responsible, as

18 Cambridge University Press, New York, 1996.

19 Above n18, 119. 
criminal accessories, to the laundering of money acquired by criminal activities - whether bribes, robbery or illegal trafficking.

The contradiction between the two decisions, that selling drugs is illegal but handling the financial proceeds of the trade is not, is putting the entire system of state authority at risk.

Non-governmental or private activity might also be of a monitoring, checking kind. I mention later the International Committee of the Red Cross. A very recent NGO is Transparency International, a body committed to combating corruption in international business. The editorial to its latest newsletter (TI Newsletter September 1997) refers to recent developments during elections in Tanzania and Papua New Guinea, sponsored by the National chapters of TI. Those chapters, says the editorial, provide further tangible evidence of the major role which civil society can play in asserting the renewal of national integrity and in containing corruption. The issue also includes the TI Corruption Perception Index for 1997 (with New Zealand fourth behind Denmark, Finland and Sweden) and records an OECD agreement on anti-corruption measures.

\section{CONSISTING ONLY OF NEUTRAL RULES OR INCLUDING MORAL PRINCIPLE?}

This analysis, particularly if you follow it through Ambassador Guéhenno's elegant presentation can produce a feeling of gloom and powerlessness. He gets to the point of suggesting that with the end of politics also comes the end of principle. What we are left with is simply rules of no moral content: ${ }^{20}$ "The gentle whirr of the social machine is sufficient unto itself."

I do not want to diminish the importance of that "gentle whirr". There is much morally neutral law that eases our daily lives. Life would be impossible if each day a new set of rules had to be worked out to give meaning to Stop signs on the streets of New Zealand or to allocate the radio spectrum world wide. The UNDP Report mentions ${ }^{21}$ the UN work on international mail delivery, the standardisation of international trade laws and investment codes, customs formalities, global environmental activities, rules governing the disposal of industrial waste, the fight against global pandemics, the preservation of the common heritage, the global collection and analysis of statistics, and international air travel.

That list moves from law which does just oil the wheels to law which is not morally neutral. I am glad it does for I think it is possible, indeed essential, to be more positive than Ambassador Guéhenno and to call attention to the governmental norms based on

20 Above $\mathrm{n} 2,58$.

21 Above n3, 92. 
moral principle agreed to at the global level. You have in front of you the example of the huge body of international labour standards prepared by an organisation with a unique tripartite structure committed to the proposition that "universal and lasting peace can be established only if it is based upon social justice", to return to the words written at Versailles.

Again I take the New Zealand example. The New Zealand statute book helps manifest, in part in a mundane way, the penetration of national law by international obligations and standards. About 200 of the 600-700 New Zealand statutes are affected in one way or another by international law. Looking at the matter alphabetically we can go from the Abolition of the Death Penalty Act to the Weights and Measures Act, the former relating to moral principle and the latter to "the gentle whirr". The two examples highlight two quite different areas of international standards. The Weights and Measures Act is designed to facilitate commerce, internationally as well as nationally. It can be traced back in formal governmental terms to the International Convention on the Metre and related treaties of last century.

\section{INCLUDING INTERNATIONAL HUMAN RIGHTS LAW}

But the beginning of the alphabet, to go back to A and the Abolition of the Death Penalty Act, also highlights the great growth of human rights law and in that particular instance the Optional Protocol to the International Covenant on Civil and Political Rights prohibiting the death penalty in those countries which accept that Protocol. New Zealand was the first to do so. The international human rights development can be seen in many respects as one which began at San Francisco when the Charter of the United Nations was prepared and the full horror of the holocaust was beginning to be understood. The second preambular paragraph to the Charter helps make the point, for the peoples of the United Nations said that they were determined in the first place to save succeeding generations from the scourge of war, and, second, to reaffirm faith in fundamental human rights, in the dignity and worth of the human person, in the equal rights of men and women, and of nations large and small.

The theme was picked up in the provisions of the Charter relating to International Economic and Social Cooperation in the drafting of which the New Zealand delegation had had a large hand, as indeed it had in the previous year influenced the preparation of the Declaration of Philadelphia at the International Labour Conference. The principal relevant article, article 55, of the Charter of the United Nations, proclaims that the United Nations is to promote higher standards of living, full employment and conditions of economic and social progress and development, with a view to the creation of conditions of stability and well-being which are necessary for peaceful and friendly relations among nations based on respect for the principle of equal rights and self-determination of peoples. 
But the representatives gathered at San Francisco in 1945 were not working on a blank slate. As indicated the International Labour Organisation had in important respects led the way on the international protection of human rights, although its work too built on earlier developments, including the prohibition of slavery and the law regulating armed conflict.

The law of armed conflict justifies a brief elaboration, given the dreadful situations that are to be seen in many parts of the world at present, situations which underline again the collapse of sovereign states and which recently have killed many more than have the orthodox wars between states. Internal wars are not peculiar to the modern age. The Americans, for instance, still remember the huge losses on both sides in their war of last century, a conflict which occurred at the time of the New Zealand wars, and many other countries have similar haunting memories in their histories.

The standards and the rules governing armed conflict, which attempt to balance military necessity and humanitarian imperatives, are updated about every generation. In that we find a gloomy recognition of the fact that notwithstanding efforts to prohibit war they still occur and rules must be written to protect humanitarian values in their midst. There are huge problems of compliance with that law, particularly if the conflict is an internal one. The principal effort should be in first order compliance. Armed forces should be trained. They should realise that very often moral, military and even political values will march together. I keep repeating, but Shakespeare so often says things so well, some words of Henry V spoken before the battle of Agincourt. He had just ordered or confirmed that one of his old drinking mates should be hanged for stealing a pyx from a church. This is what he said: ${ }^{22}$

We would have all such offenders so cut off: and we give express charge, that in our marches through the country, there be nothing compell'd from the villages; nothing taken, but paid for: none of the French upbraided or abused in disdainful language; for when Lenity and Cruelty play for a Kingdom, the gentler gamester is the soonest winner.

In those few words Henry, or Shakespeare, states both the rule and the justification for it.

But questions of governance, of the enforcement of the standards so established, continue to arise when national discipline does break down. Sometimes the answer will be in internal disciplinary and court processes as in that instance. The court processes might as well be international, as is to be seen at present in the international criminal tribunals in the Hague for former Yugoslavia and Arusha in respect of Rwanda. There are also the proposals, now well advanced, for a universal international criminal court.

22 Act III, scene 4 
To those institutional arrangements are to be added the indomitable work of the members of the International Committee of the Red Cross. The potential of other bodies and institutions established to promote compliance with the law is distressingly undeveloped. Too often the political will is lacking.

A body of principle and law for the world community exists now. It no doubt requires further development. As well the processes for that development and for national implementation requires close attention.

\section{SUPPORTED BY NATIONAL PROCESSES}

I would like to make some comments about these processes - the national and the international which I consider in turn.

\section{OF INFORMING}

The first point to be made about the national processes is to emphasise the need for information. There is, for instance, much loose talk in New Zealand as elsewhere about bloated international bureaucracies and unrealistic, unworldly standard setting. We need some facts. The regular annual budget of the United Nations is about 20 cents for each inhabitant of this globe. The figure for arms and military spending is about 500 times that at \$134 per person. The UN spending on economic and social development - of about four times the administration budget - is less than the annual budget of New York's State University. No doubt major improvements can and should be made in the UN systems - as Kofi Annan has so clearly signalled - but it is important that public understanding and attitudes are based on facts.

Those facts include the facts about the international rules and standards governing and influencing national policy and law. Commentary in New Zealand concerning for instance international trade, labour, human rights and environmental matters sometimes suggests an ignorant malign process somewhere in New York or Geneva completely out of national and democratic control. The first answer to such commentary again is better information. At the technical level we now for the first time in 50 years have a New Zealand Consolidated Treaty List ${ }^{23}$ in two substantial volumes. It is an excellent publication. The Ministry of Foreign Affairs and Trade has just published for the 35th time its incomparable United Nations Handbook, a basic resource for officials and others in New York and many other places around the world. And the Law Commission last year published A New Zealand Guide to International Law and its Sources. ${ }^{24}$

23 MFAT, NZ Treaty Series 1997, Vols 1 and 2. As at 31 December 1996.

24 J Wallace, NZLC R34, 1996. 
As well the Government could follow valuable steps recently taken in Australia to provide better information about current treaty activity. We might hope that better use is made of these sources and of the riches of the internet. Yesterday for instance I received by airmail! - a communiqué from the International Court of Justice in the Hague announcing that it now had a web site on the Internet, http://www.icj-cij-org.

\section{$X \quad$ AND CONSULTING DURING NEGOTIATION}

Information is necessary. But it may not be sufficient. Those receiving the information may wish to be involved, for instance, through consultation as treaties are negotiated.

For international labour conventions, the International Labour Organisation Constitution provides for more than consultation - union and employer representatives, along with governments, draft and adopt the texts. Consultation is increasingly to be found in other areas, for instance, in trade - where Richard Nottage, the Secretary for Foreign Affairs and Trade has provided a valuable account of the consultation followed during the GATT - Uruguay Round - and in environmental areas.

Given that more and more law is being made offshore we need, I suggest, to consider in a systematic way how New Zealanders are best to be informed about and to participate in those processes. You might like to apply part of the statement of the purpose of the Official Information Act 1982 to international affairs : as adapted it might read that the purpose is to increase the availability of international official information to the people of New Zealand as members of the world community (i) to enable their more effective participation in the making and administration of international laws and policies and (ii) to promote the accountability of those who make and administer those laws and thereby to enhance respect of the law and to promote the good government of the international community. That reformulation involves some suspension of disbelief and is rather visionary. Let me be more concrete and refer to practical steps relating to the rapidly changing world in which we live.

\section{OR AT THE TIME OF TREATY ACCEPTANCE}

The Foreign Affairs and Defence Select Committee and the Law Commission are among those who are considering those matters at present. Their attention is also directed at a second stage of treaty making - the acceptance of the treaty by the Government. The Prime Minister has also spoken positively, if rather generally, about this matter recently. 
Again there are questions about public and parliamentary involvement in that process of acceptance. Thirty-three years ago a young academic surveyed the practice of the previous 20 years and concluded: $:^{25}$

There is a constitutional convention that the Government will refer important treaties to

Parliament so that that body can consider the Government's action or proposed action.

That was a matter of constitutional convention rather than binding legal rule.

I would like to think that, taking account of the intervening practice, I would reach the same conclusion today. What I would instead like to do is to suggest, along the lines of recent Australian developments and of strengthened British practice, that the Government regularly table certain types of treaties in Parliament so that Members of Parliament and interested members of the public can express their views on treaty actions proposed by the government. That process could be assisted by the tabling as well of a national interest statement.

The Government does in fact regularly report to Parliament on its attitudes to recently adopted International Labour Conventions as required by the Constitution of the International Labour Organisation. ${ }^{26} \mathrm{I}$ am not sure that sufficient advantage is taken of that process.

Further options might be examined, including Parliament being asked to approve (or not) the acceptance of certain categories of treaties and the Government seeking that approval for those or other categories.

\section{WITH EFFECTIVE MEANS OF IMPLEMENTATION}

Closely related to the acceptance of the international obligations is of course their effective implementation in national law and policy. The Cabinet Office Manual ${ }^{27}$ requires Ministers in making legislative proposals to report on compliance with relevant international standards and obligations.

Implementation is also a matter for the courts. Globalisation appears increasingly to affect our agenda, for instance in cases over the last year relating to homecare workers, access to court documents, carriage of bulbs from a Palmerston North nursery to Amsterdam, the Ansett plane crash, criminal sentencing, immigration and refugee matters, legal aid in respect of the Human Rights Committee, and same sex marriage.

25 K Keith "New Zealand Treaty Practice : Executive and Legislature" (1964) 1 NZULR 272, 293.

26226 NZPD 822.

27 Aug 1996 (3rd ed). 
Some of those cases cause controversy about the adequacy of national implementation of international obligations, a matter which may come before international reporting and complaints processes as well, as with workers compensation and the Employment Contracts Act matters. I will return to that at the end of the discussion of the international processes to which I now turn.

\section{INTERNATIONAL PROCESSES}

I take three aspects of those processes:

- the choice of topics for international regulation and especially their definition;

- the choice of method of regulation;

- means of implementation.

\section{FOR ASKING THE RIGHT QUESTION}

On the first, the choice of topic for regulation, I return to the famous last words of Gertrude Stein. As she was about to enter the operating theatre she asked "What is the answer?" Apparently she did not get one for she then asked the more valuable question "What is the question?"

The current exchanges in the context of the WTO, the International Labour Organisation, the G7 or is it the G8 and elsewhere about the trade and questions are a topical instance. Many of you will know of the debates which led to the statement from the WTO Ministerial meeting in Singapore last December where Ministers renewed

\footnotetext{
our commitment to the observance of internationally recognised core labour standards. The International Labour Organisation is the competent body to set and deal with these standards and we affirm our support for its work in promoting them. We believe that economic growth and development fostered by increased trade and further trade liberalisation contribute to the promotion of these standards. We reject the use of labour standards for protectionist purposes, and agree that the comparative advantage of countries, particularly low wage developing countries, must in no way be put into question. In this regard, we note that the WTO and International Labour Organisation secretariats will continue their existing collaboration.
}

That is plainly just one stage, although a very important one, in that ongoing process.

Another instance of asking the right question is presented by the issues surrounding workers compensation and health and safety in employment. The facts in several countries over a lengthy period persuaded my colleagues and me in the Law Commission of the dangers of confusing the rules for the rehabilitation and compensation of those who are injured with the processes directed at accident prevention and the penalising of those who break the rules. Subsequent research supports that 
conclusion, notably Dewes, Duff and Trebilcock, Exploring the Domain of Accident Law : Taking the Facts Seriously. ${ }^{28}$

\section{PREPARING ANSWERS IN THE APPROPRIATE FORM}

The second international process matter is the choice of means of regulation. Michel Hansenne, the Director-General of the International Labour Organisation, discusses it in the report mentioned earlier in the particular context of the choice between binding Conventions and non-binding recommendations suggesting a greater use of recommendations with other associated follow up procedure. ${ }^{29}$ We should have in mind as well the role of private law making, as with the diamond industry example. A wide range of possible methods of governance - private as well as public - is available internationally as well as nationally.

\section{FOR EFFECTIVE IMPLEMENTATION}

The final international process matter is implementation - again touched on earlier. Like the others this is a vast topic. I have already indicated the critical importance of national methods of implementation. The principle of subsidiarity which appears in theological writing as well in writing about public organisation and administration emphasises the value of making decisions at the lowest appropriate level. But we must as well accept the increasing significance of international methods of implementation. This aspect of the international rule of law is of particular importance to small countries like New Zealand. It is not enough to have sound international rules. There must be methods of ensuring that they are taken seriously and sometimes those methods will be international ones.

Let me conclude with another European, a financial wizard who seems always to be in the news, George Soros. He has recently argued that "to have a stable system, you need some fundamental values to sustain it." Those fundamental values, such as social justice, cannot be attained by unrestrained competition, Soros on Soros : Staying ahead of the Curve. ${ }^{30}$ Michel Hansenne quoted those words and related them to the ILO's basic tenet : labour is not a commodity. ${ }^{31}$

What I have tried to do today is to give you a sense of the remarkable, even revolutionary, ways in which the organisation of public powers in the world is being

28 (Oxford University Press, New York, 1996). See Meyer "Just the Facts?" (1997) 106 Yale LJ 1269 and Richardson Osgoode Hall LJ forthcoming.

29 Above n11, 49-66.

30 (J Wiley, New York, 1995) 196.

31 Above n 11, 7. 
transformed, at least as I see it, and to suggest to you some ways of thinking about how those new and changed structures can be subjected to, or at least be guided by, principle and how their processes can be improved. We should not, in Ambassador Guéhenno's words, be facing the end of democracy. Rather we should be searching for the wise restraints that make us free.

\section{GOUVERNEMENT, SOUVERAINETÉ ET GLOBALISATION}

Prenant comme point de départ de sa réflexion, l'ouvrage de JM Guehénno, La fin de la democratie, l'auteur s'interroge sur les conséquences que peut avoir sur les notions traditionnelles de démocratie et de souveraineté, la mondialisation (ou la globalisation) des échange commerciaux et financiers.

Va-t-on vers la disparition de l'une et l'autre au benéfice de l'émergence de nouveaux rapports basés uniquement sur des contingences commerciales?

Illustrant son propos d'exemples tirés tant de l'évolution de la Nouvelle Zélande, que des autres parties du monde, l'auteur défend la these selon laquelle il est non seulement impératif en termes d'efficacité économique mais aussi en termes d'adaptation des gouvernements, que le droit national, néo-zelandais en particulier, intègre les différents paramêtres imposés par la globalisation des rapports (notamment ceux contenus dans les conventions et traités internationaux), même si cela doit se faire au prix d'une remise en cause parfois radicale des règles traditionelles. 